\title{
MODEL PREDIKSI PENYAKIT GINJAL KRONIK MENGGUNAKAN RADIAL BASIS FUNCTION
}

\author{
Stefanus Santosa ${ }^{1}$, Agus Widjanarko ${ }^{2}$, Catur Supriyanto ${ }^{3}$ \\ ${ }^{1}$ Politeknik Negeri Semarang \\ ${ }^{23}$ Pascasarjana Teknik Informatika Universitas Dian Nuswantoro \\ Semarang \\ ${ }^{1}$ stefanus.st@gmail.com \\ 2agus.widjanarko@gmail.com \\ ${ }^{3}$ catur.dinus@gmail.com
}

\begin{abstract}
Abstrak: Penyakit ginjal kronik adalah suatu sindrom klinis. Penyakit ini disebabkan oleh penurunan fungsi ginjal yang bersifat menahun, progresif, bersifat persisten, dan irreversibel. Diagnosa dini diperlukan agar penderitanya tidak mengalami infark ginjal atau kematian mendadak. Pencegahan dapat dilakukan melalui prediksi yang tepat. Penelitian Prediksi Penyakit Ginjal Kronik pada saat ini telah dilakukan oleh beberapa peneliti. Namun peningkatan akurasi diperlukan untuk menunjang tugas dan fungsi tenaga medis dalam menegakkan diagnosa. Saat ini tingkat akurasi model penelitian sebelumnya baru mencapai $91.71 \%$. Guna meningkatkan akurasi tersebut penelitian ini menggunakan pendekatan Radial Basis Function. Eksperimen dilakukan dengan parameter uji iterasi 500 - 10000 dan konstanta pembelajaran antara 0.15- 0.3. Dari uji coba tersebut didapatkan hasil yang lebih baik daripada penelitian sebelumnya, yakni sebesar 93.75\% pada konstanta pembelajaran 0.2 dan iterasi 2000.
\end{abstract}

Kata Kunci: Chronic Kidney Disease Prediction; Radial Basis Function

\begin{abstract}
Chronic kidney disease is a clinical syndrome. The disease is caused by a decrease in kidney function that a chronic, progressive, persistent, and irreversible. Early diagnosis is necessary so that the sufferer does not undergo renal infarction or sudden death. Prevention can be done through a correct prediction. Research of Chronic Kidney Disease Prediction at this time has been done by several researchers, but accuracy improvement is still needed. Improved accuracy is required in order to support the tasks and functions of medical personnel diagnosis. Current level of accuracy of the models previous research has only reached $91.71 \%$. To improve accuracy, this study uses Radial Basis Function approach. Experiments performed by epoch parameters iteration $500-10000$ and learning rate between 0.15- 0.3. This experiment showed better results from previous studies, which amounted to 93.75\% on a learning rate 0.2 and epoch 2000.
\end{abstract}

Keywords:

Kidney Disease Prediction; Radial Basis Function

\section{PENDAHULUAN}

\subsection{Latar Belakang}

Ginjal merupakan organ penting dalam tubuh manusia yang mengatur fungsi kesejahteraan dan keselamatan untuk mempertahankan volume, komposisi, dan distribusi cairan tubuh [1]. Fungsi ginjal secara umum mengatur $\mathrm{pH}$ tubuh manusia, konsentrasi ion mineral, dan komposisi air dalam darah, mempertahankan pH plasma darah pada kisaran 7,4 melalui pertukaran ion hidronium dan hidroksil. Akibatnya, urine yang dihasilkan dapat bersifat asam pada pH 5 atau alkalis pada pH 8 [2]. Penyakit ginjal kronik disebabkan antara lain kondisi kekebalan seseorang, inflammation, obatobatan, dan racun [3].

Data tahun 1995-1999 di Amerika Serikat insidensi penyakit ginjal kronik diperkirakan 100 
juta kasus persatu juta penduduk, sedangkan di Indonesia insidensi penyakit ginjal kronik diperkirakan 100-150 kasus persatu juta penduduk pertahunnya [4]. Dalam laporan tahunan Indonesian Renal Registry (IRR) pada tahun 2011 terdapat kenaikan dalam tindakan medis hemodialisis, peritoneal dialisis [5].

Langkah pertama dalam pengelolaan penyakit ginjal adalah penetapan diagnosis yang pasti. Diagnosis yang tepat sangat penting terutama bila diagnosis penyakit ginjal yang telah dibuat di dalamnya mengandung pengertian bahwa penderitanya mempunyai kemungkinan akan dapat mengalami infrak ginjal atau kematian mendadak. Diagnosis yang salah selalu mempunyai konsekuensi buruk terhadap kualitas hidup penderita [5].

Berdasarkan data dari pemerintah Taiwan 35 persen anggaran kesehatan, banyak terserap untuk mengobati penyakit ginjal kronik. Hal ini menjadi latar belakang penelitian yang dilakukan oleh Ruey Kei Chiu dan Renee Y. Chen [6]. Dalam penelitiannya Ruey mengajukan komparasi metode Back Propagation Neural Network ( BPNN), Generalized Feedforward Neural Network (GFNN) dan Modular Neural Network ( MNN) yang dikombinasikan dengan Genetic Algorithm ( GA). Dari hasil komparasi tersebut akurasi tertinggi $91.71 \%$ dicapai oleh BPNN, GFNN mendapatkan akurasi 91.08\% dan akurasi terendah diperoleh MNN 88.62\%.

Berdasarkan latar belakang yang telah diuraikan di atas, dapat dirumuskan bahwa: model prediksi penyakit ginjal kronik berbasis Back Propragation Neural Network pada penelitian sebelumnya masih kurang akurat sehingga perlu ditingkatkan akurasinya melalui pendekatan lain.

Guna mengatasi masalah tersebut, maka penelitian ini mengajukan pendekatan Artificial Neural Network dengan Arsitektur Radial Basis Function. Penggunaan Artificial Neural Network dengan mempergunakan arsitektur Radial Basis Function telah banyak dilakukan. Diantaranya adalah penelitian yang dilakukan oleh Loukeris Nikolas [7] yang menyebutkan Radial Basis Function lebih cepat dalam pemrosesan dibandingkan dengan Multilayer Perceptron.

Hasil penelitian yang diusulkan adalah berupa Model Prediksi Penyakit Ginjal Kronik berbasis Radial Basis Function dengan akurasi yang lebih tinggi dibanding model sebelumnya sebagai kontribusi bagi dunia iptek.

Bagi masyarakat penelitian ini diharapkan dapat memberikan kontribusi bagi upaya pengembangan aplikasi yang dapat membantu masyrakat medis utamanya dokter dan rumah sakit dalam mendiagnosis penyakit ginjal kronik dengan tingkat akurasi yang baik sehingga tindakan pencegahan terjadinya penyakit ginjal kronik dapat dilakukan.

\section{MODEL PREDIKSI PENYAKIT GINJAL KRONIK MENGGUNAKAN RADIAL BASIS FUNCTION NEURAL NETWORK}

\subsection{Penyakit Ginjal}

Gagal ginjal kronis (chronic renal failure) adalah kerusakan ginjal progresif yang berakibat fatal dan ditandai dengan uremia (urea dan limbah nitrogen lainnya) yang beredar dalam darah serta komplikasinya. Jika tidak dilakukan dialisis atau transplantasi ginjal bisa mengakibatkan kematian.

Gagal ginjal kronis (GGK) atau penyakit ginjal tahap akhir merupakan gangguan fungsi ginjal yang progresif dan ireversibel. Kemampuan tubuh gagal untuk mempertahankan metabolisme 
dan keseimbangan cairan dan elektrolit sehingga menyebabkan timbulnya uremia.

Penyakit ginjal kronik dapat dklasifkasikan menjadi 2(dua) yaitu menurut diagnosa etiologi dan derajat penyakit. Menurut diagnosa etiologi, penyakit ginjal kronik diklasifikasikan sebagai berikut [4].

Tabel 1. Penyebab Penyakit Ginjal Kronik [4]

\begin{tabular}{|c|c|}
\hline Penyakit & Tipe Mayor \\
\hline $\begin{array}{l}\text { Penyakit Ginjal } \\
\text { Diabetes }\end{array}$ & Diabetes tipe 1 dan 2 \\
\hline $\begin{array}{l}\text { Penyakit Ginjal } \\
\text { non Diabetes }\end{array}$ & $\begin{array}{l}\text { Penyakit Glomerular } \\
\text { (penyakit autoimun, infeksi } \\
\text { sistemik, obat, neoplasia) } \\
\text { Penyakit vascular (penyakit } \\
\text { pembuluh darah besar, } \\
\text { hipertensi, mikroangiopati) } \\
\text { Penyakit tubulointerstisial } \\
\text { (pielonefritis kronik, } \\
\text { obstruksi, keracunan obat) } \\
\text { Penyakit kistik (ginjal } \\
\text { polikistik) }\end{array}$ \\
\hline $\begin{array}{l}\text { Penyakit pada } \\
\text { transplantasi }\end{array}$ & $\begin{array}{l}\text { Rejeksi kronik keracunan } \\
\text { obat penyakit recurrent }\end{array}$ \\
\hline
\end{tabular}

Klasifikasi PGK menurut derajat penyakit dikelompokkan menjadi 5 derajat, berdasarkan atas penurunan faal ginjal berdasarkan LFG, yaitu [4] :

Tabel 2. Derajat Penurunan Faal Ginjal [4]

\begin{tabular}{|l|l|}
\hline Derajat & LFG (mL/meit/1,73 m) \\
\hline G1 & $=90$ \\
\hline G2 & $60-89$ \\
\hline G3a & $45-59$ \\
\hline G3b & $30-44$ \\
\hline G4 & $15-29$ \\
\hline G5 & $<15$ \\
\hline
\end{tabular}

Pendataan pasien ginjal biasanya meliputi 25 atribut diantaranya 11 atribut dengan data numerik (Age, Blood Pressure, Blood Glucose Random, Blood Urea, Serum Creatinine, Sodium, Potassium, Hemoglobin, Packaged Cell Volume, WBC count, RBC count) dan 14 atribut dengan data nominal yaitu (Specific Gravity, Albumin, Sugar, RBC, Pus cell, Pus cell clumps, Bacteria, Hypertension, Diabetes Mellitus, Coronary Artery Disease, Appetite, Padal Edema, Anemia, and Class).

Berdasarkan data yang terkandung pada setiap atribut tersebut yang terkumpul dari pasien- pasien ginjal kronik, maka dapat dilakukan pengolahan agar terbentuk suatu model yang dapat digunakan untuk memprediksi seseorang memiliki kecenderungan berpenyakit ginjal kronik ataukah tidak. Pemodelan prediksi penyakit ginjal kronik dapat dilakukan melalui teknik komputasi cerdas.

\subsection{Konsep dari Model Prediksi Penyakit Ginjal \\ Penelitian ini mengajukan pendekatan} Artificial Neural Network dengan Arsitektur Radial Basis Function untuk meningkatkan akurasi dan waktu dari penelitian yang telah dilakukan sebelumnya Beberapa penelitian telah mempuyai akurasi yang cukup baik, namun masih perlu ditingkatkan agar performanya dapat menghasilkan akurasi tinggi, sehingga prediksi lebih akurat.

Hal yang bersifat khusus pada jaringan syaraf tiruan $R B F$ ialah sebagai berikut [8] :

a. Pemrosesan sinyal dari input layer ke hidden, sifatnya nonlinier, sedangkan dari hidden layer ke output layer sifatnya linier.

b. Pada hidden layer digunakan sebuah fungsi aktivasi berbasis radial, misalnya fungsi Gaussian. 
c. Pada output unit, sinyal dijumlahkan dengan metode ordinary least square.

d. Sifat jaringannya ialah satu arah, tidak seperti pada jaringan feed foward neural network (FFNN) yang bersifat bolak-balik. [8]

Pembentukan struktur jaringan pada $R B F$ ditentukan oleh 3 buah parameter yang dapat disesuaikan yaitu titik pusat dan lebar jarak antara hidden layer dan bobot koneksi dari hidden layer ke output layer. Pembangunan struktur Radial Basis Function menganut aturan secara umum yaitu :

\section{a. Basis Function Centers}

Pada tahapan ini dilakukan proses pemilihan basis function center, distribusi training sample, dan memilih $s$ sebagai titik pusat menggunakan fungsi Gaussian :

$$
\sigma=\frac{d}{\sqrt{2 s}}
$$

b. Basis Function

Pada tahapan ini penentuan clustering dimaksudkan sebagai dasar untuk memlilih basis function. Metode yang dipergunakan adalah algortima K-Means, dan dilakukan iterative formula untuk memodifikasi training error. Untuk mengoptimalkan struktur jaringan $R B F$ digunakan rumus:

$$
e=\sum_{k=1}^{n}\left(t_{k}-y_{k}\right)^{2}
$$

Keterangan:

$e$ adalah error

$t$ merupakan target, dan

$y$ adalah output.

Radial Basis Function memiliki kelebihan lebih cepat dalam melakukan training data, dan ketepatan dalam estimasi. Kecepatan dan ketepatan dalam estimasi dipengaruhi oleh parameter bobot koneksi dari Radial Basis Function ke output layer dan panjang dari pusat yang ada pada Radial Basis Function.

\section{3. $\quad$ Proposed Model}

Hasil penelitian berupa Model tentang prediksi penyakit ginjal kronik yang dimodelkan dengan arsitektur $R B F$ dengan parameter utama yaitu hidden layer, fungsi aktivasi, dan neuron size. Dalam menentukan hidden layer dipergunakan metode penentuan center menggunakan Algortima K-Means dan Pseudo Invers [9]. Sedangkan penentuan fungsi aktivasi menggunakan Gaussian Function.

Penelitian ini menggunakan adaptive system, yakni proses adjustment struktur jaringan dan bobot koneksi dilakukan tanpa intervensi dari manusia,

\section{METODE PENELITIAN}

Penelitian ini menggunakan metode eksperimen. Penelitian ini bertujuan untuk meningkatkan akurasi dalam memprediksi penyakit ginjal kronik menggunakan algoritma Radial Basis Function Neural Network untuk menganalisis data penderita penyakit ginjal kronik.

\subsection{Pengumpulan Data}

Data yang di pergunakan dalam penelitian ini merupakan data sekunder yang di dapatkan dari https://archive.ics.uci.edu/ml/datasets/Chronic _Kidney_Disease. Data ini disusun oleh L.Jerlin Rubini (Research Scholar) Alagappa University dan Dr. P.Soundarapandian. M.D.,D.M (Senior Consultant Nephrologist), Apollo Hospitals, Managiri, Madurai Main Road, Karaikudi, Tamilnadu, India.

Dataset ini tersusun atas 25 attributes, 400 instances, serta 2 kelas yaitu CKD dan NOTCKD dengan distribusi masing - masing sebesar $63 \%$ untuk CKD dan 37\% untuk NOTCKD. Dataset ini mempuyai 2 atribut tipe data yaitu Numerical dan 
Jurnal Pseudocode, Volume III Nomor 2, September 2016, ISSN 2355-5920

Nominal. Data numerik terdiri dari 11 atribut antara lain: Age, Blood Pressure, Blood Glucose Random, Blood Urea, Serum Creatinine, Sodium, Potassium, Hemoglobin, Packaged Cell Volume, WBC count, RBC count. Data nominal terdiri dari 14 atribut antara lain: Specific Gravity, Albumin, Sugar, RBC, Pus cell, Pus cell clumps, Bacteria, Hypertension, Diabetes Mellitus, Coronary Artery Disease, Appetite, Padal Edema, Anemia, dan Class.

3.2. Mendefinisikan Jaringan dan Struktur Algoritma Pelatihan

Pada tahap ini dilakukan pembangunan struktur jaringan awal dari Radial Basis Function. Tahapan dalam membangun jaringan RBF adalah sebagai berikut [10] [9] [11] [12].

\section{a. Penentuan Basis Function}

Dalam membangun jaringan $R B F$ fungsi aktivasi pada hidden layer ditentukan berdasarkan fungsi berbasis radial, dalam penelitian ini adalah fungsi Gaussian. Fungsi Gaussian dapat didefinisikan sebagai berikut :

$$
\phi_{j}=\exp \left(-\frac{\left(x-C_{j}\right)^{2}}{2 \sigma_{j}^{2}}\right)
$$

b. Penentuan Center

Di dalam RBF Neural Network salah satu metode yang dipergunakan dalam penentuan center adalah dengan menggunakan algortima K-Means. Pseudo code algortima K-Means sebagai berikut.

Algoritma K-Means Clustering

$$
\begin{aligned}
& \text { Input } \quad \text { Koleksi Dokumen } D=\{d 1, \\
& d 2, d 3, \ldots d n\} ; \\
& \text { Jumlah cluster ( } k \text { ) yang } \\
& \text { akan dibentuk; }
\end{aligned}
$$

\author{
Output : $k$ cluster; \\ Memilih $k$ dokumen untuk dijadikan
} centroid (titik pusat cluster) awal secara random;

c. Perhitungan Jarak

Perhitungan jarak setiap dokumen ke masingmasing centroid menggunakan persamaan cosines similarity (persamaan 3), kemudian dijadikan satu cluster untuk tiap-tiap dokumen yang memiliki jarak terdekat dengan centroid;

$$
\operatorname{Dist}_{X Y}=\sqrt{\sum_{k=1}^{m}\left(\mathrm{X}_{i k}-X_{j k}\right)^{2}}
$$

d. Penentuan Centroid Baru

Centroid baru ditentukan dengan cara menghitung nilai rata-rata dari data yang ada pada centroid yang sama. Jika posisi centroid baru dan centroid lama tidak sama maka proses akan kembali ke langkah 2

e. Penyusunan arsitektur jaringan $R B F$

Dari perhitungan dengan menggunakan algoritma K-Means didapatkan nilai center, yang menentukan jumlah neuron pada hidden layer. Pada penelitian ini input data untuk jaringan $R B F$ adalah 24 atribut penyebab penyakit ginjal kronik. Sedangkan output akhir jaringan $R B F$ prediksi seseorang terkena penyakit ginjal kronik.

\subsection{Pembaharuan Bobot}

Algoritma pelatihan $R B F$ adalah sebagai berikut [13][14]. Sebelum pembaharuan bobot ditetapkan, perlu ditentukan dulu parameter parameter sebagai berikut :
a. Inisialisasi iterasi maksimal ( epoch)
b. Learning Rate $\alpha$
c. Nilai Spread yang di tetapkan sebesar $=\frac{d_{\max }}{\sqrt{n}}$ 
Langkah - langkah dalam melakukan pembaharuan bobot dapat dijelaskan sebagai berikut :

a. Meneruskan sinyal ke hidden layer dan menghitung nilai tugas aktivasi dengan fungsi Gaussian

$$
\begin{gathered}
\phi_{j}=\exp \left(-\frac{\left(x-C_{j}\right)^{2}}{2 \sigma_{j}^{2}}\right) \\
\phi_{j}=\exp \left(-\frac{\left(x-C_{j}\right)^{2}}{2 \sigma_{j}^{2}}\right)
\end{gathered}
$$

a. Membentuk Matriks Gaussian :

b. Menghitung Pseudoinverse dari Matriks Gaussian

c. Menghitung hasil pseudoinverse dikalikan dengan target

d. Mendapatkan nilai awal bobot dan bias.

e. Menghitung Output dari Jaringan $R B F$ : $Y_{1}=W_{1} * \varphi_{1}+W_{2} * \varphi_{2}+B$

f. Mengubah Bobot dengan LMS ( Least Mean Square)

$w(k+1)=w(k)+\alpha \cdot[d(k)-y(k)] \cdot x(k)$

$\mathrm{w}(\mathrm{k}+1)$ : Bobot pada cacah ke $\mathrm{k}+1$

w(k) : Bobot pada cacah ke k;

$\alpha \quad$ : Laju konvergensi $(0<\alpha<1)$

$\mathrm{x}(\mathrm{k}) \quad$ : Masukan yang diboboti

d(k) : Keluaran yang diinginkan

$\mathrm{y}(\mathrm{k}) \quad$ : Keluaran aktual;

$d(k)-y(k)$ : Sinyal error yang merupakan data latih

\subsection{Validasi}

Proses validasi dilakukan dengan mengamati hasil prediksi dengan menggunakan metode 10fold cross-validation. Cross-validation membagi data menjadi 2 (dua) yaitu data training sample yang dipergunakan oleh setiap algortima dan data validation sample yang dipergunakan Cross- validation untuk mengestimasi risiko terkecil dari suatu algoritma. Pengukuran kinerja diperlukan untuk mengetahui akurasi dari model yang diusulkan dalam prediksi pernyakit ginjal kronik [15] [16] [17].

Tahapan cross-validation dilakukan dengan membagi data menjadi k subset yg berukuran sama dan menggunakan setiap subset untuk data testing dan sisanya untuk data training yang dimulai dari subset pertama dan seterusnya.

\subsection{Evaluasi Hasil}

Tahap evaluasi dilakukan dengan mengamati hasil akurasi prediksi menggunakan Confusion Matrix. Validasi dilakukan dengan mengukur hasil akurasi model yang digunakan untuk prediksi dengan data acuan [10]. Pengukuran kinerja dilakukan dengan menerapkan model sehingga dapat diketahui akurasi model tersebut.

\section{ANALISIS HASIL UJI COBA PEMODELAN RBF}

Dari hasil pengumpulan data yang diperoleh ditemukan sebanyak 70 persen instance yang mempuyai atribut kosong dengan rincian 280 baris data yang mempuyai atribut kosong dari 400 instance yang ada, sehingga diperlukan pengisian nilai yang kosong. Untuk mengatasi nilai atribut yang kosong dilakukan dengan metode Mean Imputation. Mean Imputation merupakan metode yang mengganti missing value pada atribut dengan nilai rata rata yang diperoleh dari seluruh atribut yang diketahui nilainya [18].

Eksperimen yang dilakukan dalam penelitian ini yang meliputi pengenalan data pelatihan dan pengujian dengan menggunakan jaringan Radial Basis Function baik dilihat dari waktu komputasi 
pelatihan dan pengujian, pengaruh epoch dalam proses pelatihan, serta konstanta pembelajaran yang dapat dipergunakan, dimaksudkan agar tingkat pelatihan dan pengujian mendapatkan akurasi yang terbaik.

Pengujian dilakukan dengan bahasa pemograman Java dengan menggunakan library Neuroph. Pengujian dilakukan dengan terlebih dahulu menentukan laju pembelajaran dan iterasi terbaik untuk memprediksi penyakit ginjal kronik pada arsitektur jaringan Radial Basis Function dengan menentukan nilai Learning Rate 0.05 sampai dengan 0.3, dan nilai epoch 500 sampai dengan 10.000. Arsitektur jaringan Radial Basis Function tersusun dengan Input layer sebanyak 24 Neuron, 1 Hidden layer dengan 2 Neuron, dan 2 Output Layer dengan 2 Neuron. Hasil perhitungan tercantum pada tabel 2 berikut.

Tabel 3. Hasil Ujicoba Radial Basis Function

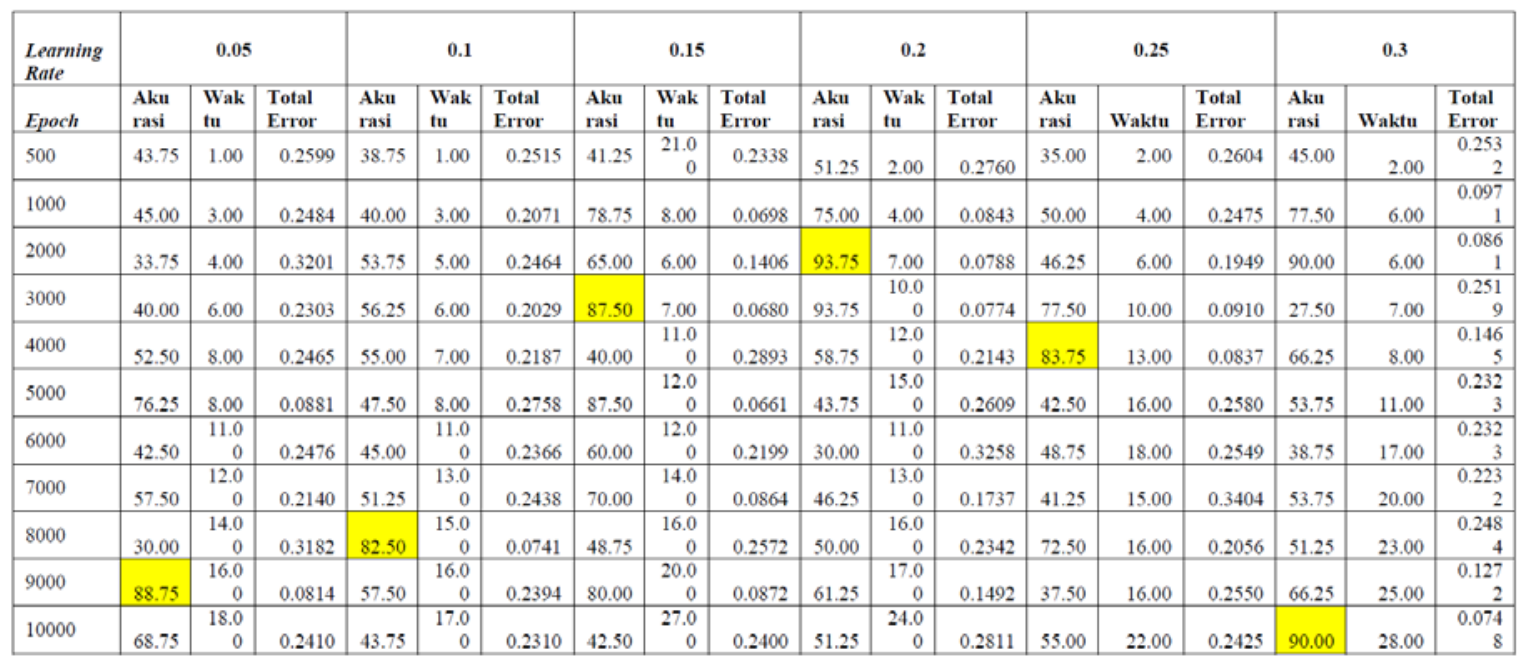

Dari tabel tersebut tampak bahwa akurasi terbaik tercapai pada angka 93.75\%. Angka ini dicapai pada konstanta pembelajaran sebesar 0.2 dengan iterasi 2000. Hasil eksperimen menunjukkan bahwa akurasi terbaik model prediksi Radial Basis Function dicapai pada Learning Rate 0.2 dengan iterasi 2000 sebesar 93.75\%.

Merujuk pada penelitian Ruey Kei Chiu dalam Research Article Intelligent Systems Developed for the Early Detection of Chronic Kidney Disease [6], terhadap prediksi penyakit ginjal menggunakan metode Back Propagation Neural Network, didapatkan akurasi sebesar $91.71 \%$ dengan parameter model sebagai berikut: fungsi aktivasi Tanh, jumlah hidden layer sebanyak 2, jumlah neuron pada hidden layer sebanyak 5, dengan epoch max 3000. Model prediksi penyakit ginjal kronik dengan Radial Basis Function yang diusulkan penulis terbukti lebih baik daripada model penelitian sebelumnya dengan akurasi yang mencapai 93.75\%.

\section{PENUTUP}

\subsection{Kesimpulan}

Dalam penelitian ini dilakukan pemodelan untuk mendapatkan arsitektur dan algortima pembelajran terbaik untuk memprediksi penyakit ginjal kronik sehingga didapatkan pemodelan yang mempuyai akurasi tinggi yang lebih baik dari penelitian sebelumnya. Dengan arsitektur Artificial Neural Network pada layer input yang terdiri 24 node, 
dengan 2 Neuron pada hidden layer, dan 2 kelas pada layer ouput, dilakukan uji coba dengan perubahan pada nilai Learning Rate 0.05; 0.1 ; 0.15 ; 0.2 ; 0.25 ; dan 0.3, Sedangkan parameter epoch yang diujikan 500, 1000, 2000, 3000, 4000, 5000, 6000,7000, 8000, 9000, 10000. Dari hasil pengujian tersebut didapatkan akurasi terbaik 93.75\%. pada parameter Learning Rate 0.2 dan epoch sebesar 2000. Dibandingkan dengan penelitian sebelumnya yang menggunakan Back Propagation Neural Network, proposed model prediksi penyakit ginjal kronik dengan Radial Basis Function yang dipersembahkan penulis terbukti lebih baik daripada model penelitian sebelumnya yang memiliki $91.71 \%$.

\subsection{Saran}

Penentuan bobot pada RBF kurang optimal. Oleh sebab itu diperlukan optimasi dalam pembobotan guna membentuk jaringan RBF. Salah satunya dapat menggunakan Genetic Algorithm. Dengan
Genetic Algorithm akan diperoleh gen yang berisi nilai real yang mewakili bobot basis di hidden layer pada jaringan RBF sehingga diharapkan jaringan RBF akan bekerja optimal.

\section{REFERENCES}

[1] V. M. Nurani1 and S. Mariyanti, "Gambaran Makna Hidup Pasien Gagal Ginjal Kronik yang Menjalani Hemodealisa,” Fakultas Psikologi Universitas Esa Unggul, 2011.

[2] ”Wikipedia,” 20 Februari 2015. [Online]. Available: https://id.wikipedia.org/wiki/Ginjal. [Använd 28 Agustus 2015].

[3] M. Lisa B. Bernstein, ”Web MD,” National Institute of Diabetes and Digestive and Kidney Disease, 02082015. [Online]. Available: http://www.webmd.com/a-to-zguides/understanding-kidney-disease-basic-information. [Använd 0208 2015].

[4] P. B. Pranata, ”Hubungan Kadar Asam Urat Dalam Darah Pada Penderita Penyakit Ginjal Kronik Dengan Kejadian Artitis Gout di RSUD R> Moewardi," Universitas Muhammadyah Surakarta, Surakarta, 2013.

[5] I. R. R. (IRR), "4 th Report Of Indonesian Registry," Jakarta, 2011.

[6] R. K. Chiu och R. Y. Chen, "Intelligent Systems Developed for the Early Detection of Chronic Kidney Disease," Advances in Artificial Neural Systems, p. 7, 2013. 